\title{
Amalgamation triggers linguistic constitutional challenge
}

Previously published at www.cmaj.ca

$\mathrm{F}$ rancophone organizations are rallying around an Acadian group that has mounted a legal challenge to New Brunswick's decision to whittle its eight regional health authorities to two.

The groups charge that the amalgamation infringes on the constitutional right of linguistic minorities to have separate and equal institutions.

The showdown was triggered by a March 2008 decision by the Liberal government to combine four health districts that covered largely francophone regions, primarily in the province's north, into a body called "Regional Health Authority A." The four health authorities encompassing the mainly English area of the province, largely in the south, were reconfigured under "Regional Health Authority B."

Premier Shawn Graham's government said the move would save millions of dollars and drastically improve health care. It also claimed the overhaul was needed to improve cooperation between the regions, which were often referred to as competing "silos."

But the move set off protest within the province's francophone and Acadian communities, particularly over the abolition of the Beauséjour Regional Health Authority - the province's only officially francophone health district.

Égalité santé en français argued that the reform created two unequal health authorities and launched its legal challenge. Francophone groups and politicians threw their support behind that battle at a press conference in Ottawa, Ontario. Those included the chief executive officer of Montfort Hospital, which was at the centre of a similar clash over francophone language and cultural rights a decade ago.

Arguments on the issue are scheduled to be made in a Miramichi court starting July 13 - with Égalité santé en français represented by former Supreme Court of Canada Justice Michel Bastarache.

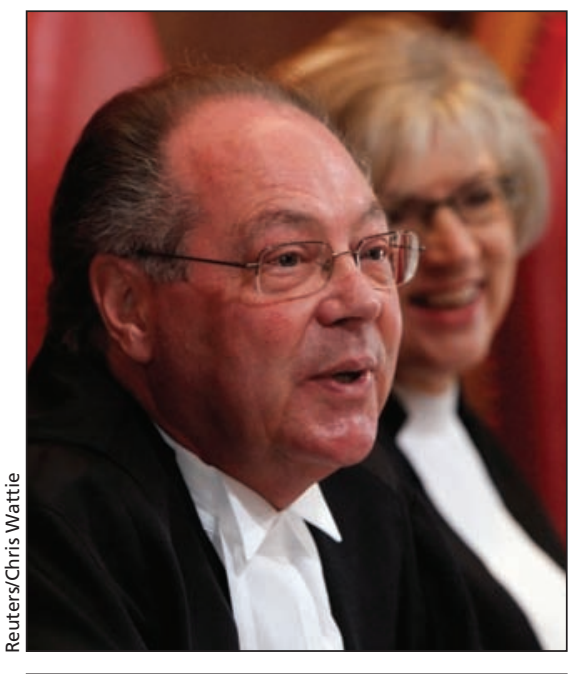

"We have the right to run our own institutions in parallel with those in the majority," says former Supreme Court of Canada Justice Michel Bastarache.

According to Bastarache, both the Canadian Constitution and New Brunswick law guarantee the equality of the anglophone and francophone language communities, as well as their right to "homogeneous" institutions.

The group essentially argues that region $\mathrm{B}$ is anglophone, while region $\mathrm{A}$ is bilingual. But a bilingual health district does not satisfy the government's obligation to francophones, argues Bastarache. Only a health authority managed and governed by francophones can properly preserve the minority's rights.

Basically, the group argues region A should be run like the old Beauséjour health district, which was officially francophone.

"We have the right to institutions that are French because we (need) a health plan that is designed according to the needs of the French population. And we have the right to run our own institutions in parallel with those in the majority," Bastarache says.

"That is the only way you get equal services. Otherwise, it's an English institution that accommodates the minority. That is a big difference," he adds. "We've had experience with bilingual institutions and it's always a situation where the minority gets the short end of the stick. ... What we want is real equality."

The New Brunswick government, however, insists the changes still provide both communities with sufficient control over their health care institutions.

For example, hospitals that previously operated in French, like Moncton's Dr. Georges-L. Dumont Regional Hospital - the flagship of francophone health care in the province - can continue to do so.

As well, health authority board meetings will be conducted in each district's majority language (English for region $\mathrm{B}$ and French for region $\mathrm{A}$ ).

But the two regional health authorities will not be defined primarily along linguistic lines, says Bernard Thériault, chief of staff for Graham. "We won't have separate French and English medical systems," he says. "We'll have one system in New Brunswick."

"The first mandate of Regional Health Authority A is not to serve the francophone community - it's to serve the people of New Brunswick, in a region where the majority is French," he adds. "However, we understand the French community... has the right to manage their own system."

But Égalité santé en français argues the reform is unconstitutional because it unfairly concentrates the bulk of specialized health services in the anglophone-dominated district. The group says many tertiary care services are offered in duplicate or triplicate in region B but aren't available at all in region $\mathrm{A}$.

"It is quite unequal and creates, in effect, two types of patients in New Brunswick," says Dr. Hubert Dupuis, the group's president. "There are those who have access to all the services the anglophone population. While others - in the francophone population do not have full and equal access and are the losers in this reform."

Dupuis, a family physician, says 
francophone patients are forced to travel to anglophone-run hospitals, where bilingual services are lacking.

The province acknowledges the disparity between the two regions, but Theriault says that's one of the reasons why the overhaul was needed: to close the gap and boost services in region $\mathrm{A}$.

"We have improved the quality and level of services for francophones by making things more efficient and by establishing a line of communication," he says.
For Dr. Bernard Leduc, the New Brunswick legal fight clearly resembles a battle fought a decade ago over Montfort Hospital in Ottawa, Ontario.

In the late 1990s, an Ontario commission recommended closing Montfort Hospital as part of a restructuring plan.

The proposal, however, was successfully challenged in the Ontario courts, which concluded that as a cultural institution, the Montfort was essential to the survival and well-being of the Franco-Ontarian community, and that its closure was unconstitutional.

"The judgment recognized that Montfort was more than a hospital that it was a very important institution in preventing assimilation. It was a way for the francophone culture in Ottawa to sustain itself," says Leduc, a family physician and the hospital's chief executive officer. "The minority rights of francophones are not negotiable." Quentin Casey, Halifax, NS

DOI:10.1503/cmaj.109-3216

\section{Health care in Romania: Fighting collapse}

Previously published at www.cmaj.ca

"With a 2010 health care budget of $3.6 \%$ of GDP, Romania comes last in the European Union in terms of health care financing. Moreover, since that the last trimester of 2009 was financed with credits from the 2010 budget, the real figure for this year is around $2.3 \%-2.6 \%$ of GDP. This money will only last until July 2010." — Romanian College of Physicians in a Jan. 7 press release

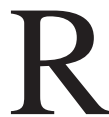

ather remarkably, Atilla Cseke, Romania's minister of health, didn't dispute the notion that his country's health care system is so underfinanced that it is facing imminent collapse. "We must find additional financial resources for the second half of 2010," he told a press conference in late January.

Cseke's hopes of staving off collapse rest on more efficient use of existing funds, elimination of waste and the introduction of copayments.

Yet, miracles shouldn't be expected.

For years, Romania's health care system has struggled to cope with underfunding.

Most hospitals in the country are in debt and even large university hospitals often lack basic supplies, such as surgical gloves and antibiotics, forcing patients to pay for such amenities out of pocket. Many buildings are in serious need of repair and sanitization. The conditions - most of which Canadians could not imagine — are fodder for the

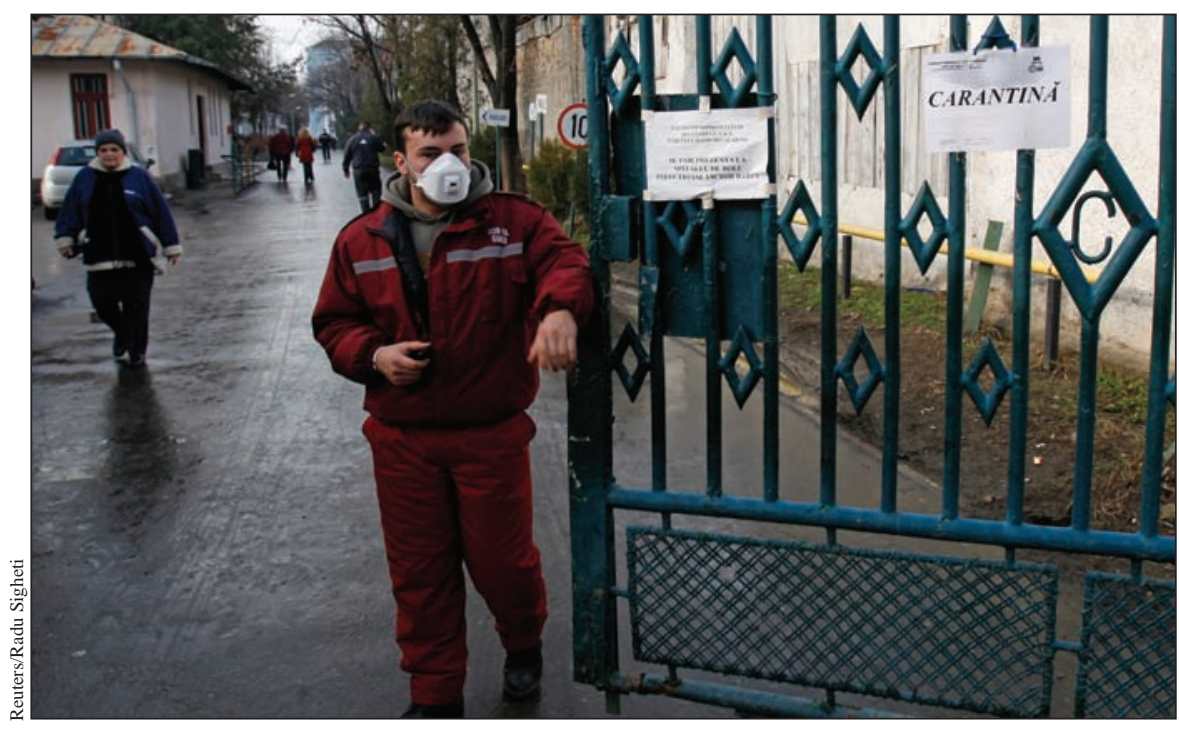

A guard closes the gate of Matei Bals Hospital, where Romanians had queued to be vaccinated against the pandemic (H1N1) 2009 flu virus in January.

media. Imagine rusted surgical instruments, rusted examination beds, cracked and damp walls, dirty toilets and, occasionally, cockroaches.

These may be extreme examples, but the fact remains that for a European Union country in the 21 st century that has managed advances in many other sectors of the economy and society, health care continues to lag significantly behind.

The country has had a mandatory health insurance scheme covering all citizens since 1998, administered by a National Insurance House that contracts services from providers. But it is chronically underfunded and notoriously inefficient in allocation of resources.

Compounding the problem is the medical brain drain faced by Romania, which now has one of the lowest ratios of physicians per population in Europe (Box 1). The Romanian College of Physicians reported that more than 4000 doctors - mostly junior doctors - have emigrated since 2007, representing almost $10 \%$ of doctors in the country.

The primary reason is financial: salaries for young doctors in Romania are 10-to-15 times lower than in Western Europe and low in comparison to the average Romanian salary. A resident in Romania typically earns $€ 200$, as compared the average worker's salary of $€ 320$.

"I don't want to leave Romania, my family and friends," says a young doc- 